\title{
Insight as a Turning Point for Learning in Executive Coaching
}

\author{
Sophie Ménard \\ Director, Leadership, Learning and Organizational Development \\ University of Ottawa
}

\begin{abstract}
The aim of this paper is to explore the inner workings of executive coaching and to offer an explanation for its effectiveness in developing leadership. In today's organizations, formal education programs meet only 10 to $20 \%$ of organizational needs in leadership development. This calls for other strategies that can effectively address the current gap in leadership capabilities. Executive coaching provides a personalized, structured, informal and action-based learning process, focused mainly on developing leadership in other words, on increasing the effectiveness of an individual's relational capabilities. It involves a relationship and trust building process, and an incremental learning process based on feedback, insession interventions, and assignments between sessions that contribute to deep learning and behaviour change. Insight is a key factor in learning and behaviour change during Executive coaching and can be observed as significant events reported by coachees.
\end{abstract}

\section{Introduction}

This article presents the practice of executive coaching and the role of insight as key factors in adult learning.

Executive coaching is a one-on-one, personalized and confidential accompaniment practice between a coach and a senior manager that supports action learning [1]. The learning supported by this coaching practice is comparable to what Grant \& Cavanagh [2] refer to as self-regulatory and consisting of metacognitive skills. Indeed, this type of coaching differs from managerial, sport or life coaching by its use of psychometric instruments to determine the person's current potential and by the use of multi-rater instruments that collect feedback from various people who are in contact with the executive being coached [4]. The aim of executive coaching is to render clients autonomous enough to be able to function and continue to expand their capabilities without the accompaniment of a coach [2].

Some researchers describe it as a process for changing behaviour using a systemic approach [4]. Still other researchers describe executive coaching in terms of skill development through the promotion of greater self-awareness [5, 6]. Despite these different perspectives on the process of executive coaching, this form of organizational development consulting remains [18] a way to develop and support leadership skills, which, in exchange, will enable organizational performance. Weller \& Weller [7] stipulate that $45 \%$ of organizational performance arises from the quality of executive leadership. Since only 10 to $20 \%$ of leadership preparation is currently being met through formal education such as MBA programs [3], other learning and development strategies must be effectively put in place to address the 80 to $90 \%$ of leadership development skills required in order to upgrade and maintain skill levels. As Bouteiller [8] mentions, competencies have a life span and require regular upkeep. In response to this development need, executive coaching offers a structured, informal and actionbased learning process that is catered to the specific needs of each client. It thus ensures that the appropriate leadership skills are targeted and developed.

Although it can be argued that leadership can be developed through workshops, the particularity of executive coaching is clearly its focus on leadership development. Since the concept of leadership has already been defined in so many ways, the definition of leadership used in this article relates specifically to the effectiveness of a person's relational capabilities. McCall [9] holds that $82 \%$ of executives experience failure in their careers, in part, because they do not know how to manage relations in the realm of teamwork and partnership building. Le Boterf [10], a researcher in the field of competencies, refers to these relational competencies as knowing how to act and adapt one's behaviour to different situations and people.

This section has established how executive coaching aims to develop leadership competencies and has expanded on the meaning of leadership in this type of adult learning practice. The following section will describe the process of executive coaching.

\section{The Executive Coaching Process}

Joo [11] describes participation in the process of executive coaching as either voluntary or as an organizational practice. The process usually consists of a series of phases; their number varies depending on the coaching model. An empirical study on 
coaches' intervention strategies and types of insight in executive coaching conducted by Ménard [1] presents a four-part coaching process consisting of the following: 1. needs clarification, 2. coaching intervention, 3. convergence, and 4. follow-up. Each part consists of various activities and interventions initiated by the executive coach. While Ménard [1] describes a four-part coaching process in her study, Dingman's [3] study on the effects of executive coaching examines the relationship between the executive coaching process and the quality of the coaching relationship as regards self-efficacy and four job-related attitudes. It presents an executive coaching process comprised of six components based on work by Kilburg [5]. Dingman's [3] argument for proposing these six specific constructs is based on her in-depth study of ten alternative coaching models and her realization that their general process themes could fit under Kilburg's [5] executive coaching process constructs. These constructs and the phases of coaching from ten other models are shown in Table 1.

These executive coaching models have been presented in order to illustrate that the coaching process can essentially be similar among practitioners, despite their differing vocabularies. The practice of executive coaching embodies not only a relationship and trust building process, but also an incremental learning process that is based on feedback, in-session interventions and assignments between sessions that contribute to deep learning and behaviour change. The following section will address the learning process in executive coaching and the integral part played by insight.

\section{Experiential Learning in Executive Coaching}

The field of adult education has long been aware that formal learning activities are just one means toward adult learning [12]. However, "while andragogy may have contributed to our understanding of adults as learners, it has done little to expand or clarify our understanding of the process of learning," nor has it achieved the status of "a theory of adult learning" [13] in Merriam [12]. In addition to the fact that the field of andragogy is one of the pillars for understanding adult learning, selfdirected learning is also a key area of research, as presented in Merriam [12].

The orientation of self-directed learning seems to vary depending on each researcher's philosophical orientation. For example, in humanistic philosophy, researchers define self-directed learning as developing the learner's capacity to be self-directed $[14,15]$. A second orientation of self-directed learning stems from reflection orientation, or "constructivism." A third philosophical stream in self-directed learning comes from behaviourism and neo-behaviourism and is reflected in the field of instructional design, which overlaps with the field of adult self-directed learning.

Ménard's [1] study, on the relation between coaches' interventions and the emergence of insight, has produced interesting data on the process of learning in intermediate and senior-level managers within the context of executive coaching that may open an avenue toward studying self-direction at a new level.

Because the goal of executive coaching is to render coachees autonomous by helping them develop self-regulatory and meta-cognitive skills with the support of experiential learning, it encourages transformational and self-directed learning. Indeed, the entire executive coaching process is based on coachees' needs and learning objectives. Coachees are encouraged to become selfaware and aware of others through feedback and experiential exercises proposed by the executive coach. As Hansman [16] stipulates, "the learning is in the doing or the experience," (p. 46) and autonomous thinking is due, in part, to transformative learning [17].

This said, it would appear that transformative learning occurs through deep learning and in order to achieve this, insight is a key factor [1]. The following section will describe various types of insight as significant events occurring during executive coaching.

\section{Types of Insight in Executive Coaching}

Indeed, insight has been defined as a sudden shift [18] and cognitive restructuring of one's experience [1] which leads to a new affective experience and understanding of a circumstance. Insight emerges from experience; it allows a person to create his or her own personal experience and interpret the meaning of circumstances encountered, which is why it is important for adult learning.

A study conducted in 2010 by De Hann, Bertie, Day \& Sills [18] on significant moments or events experienced by clients during executive coaching surveyed 3,201 alumni of a university in England who had experienced coaching. Sixty-seven respondents sent in their responses. Twenty respondents had experienced no significant event, whereas 47 had experienced 59 such moments, also referred to by the authors as suboutcomes. The authors describe suboutcomes as moments within coaching sessions, whereas outcomes are results observed at the end of the coaching process. According to the authors, 
Table 1. The effects of executive coaching on job-related attitudes. Regent University, School of Leadership Studies, In partial fulfillment of the requirements for the degree of Doctor in Organizational Leadership

(Dingman, M.E. (2004).

\begin{tabular}{|c|c|c|c|c|c|c|c|c|c|c|}
\hline $\begin{array}{l}\text { Kilburg } \\
\text { (1996b) }\end{array}$ & \begin{tabular}{|c|} 
Kiel, Rimmer, \\
Williams, \& Doyle \\
(1996)
\end{tabular} & $\begin{array}{l}\text { Saporito } \\
\text { (1996) }\end{array}$ & $\begin{array}{l}\text { Giglio, Diamante } \\
\text { \& Urban (1998) }\end{array}$ & $\begin{array}{l}\text { Peterson } \\
\text { (1996) }\end{array}$ & $\begin{array}{l}\text { Bricklin } \\
\text { (2001) }\end{array}$ & $\begin{array}{l}\text { Orenstein } \\
(2000)\end{array}$ & $\begin{array}{l}\text { Kampa- } \\
\text { Kokesch \& } \\
\text { Anderson } \\
(2001)\end{array}$ & Kilburg (2001) & $\begin{array}{l}\text { Sztucinski } \\
\text { (2001) }\end{array}$ & $\begin{array}{l}\text { Thach } \\
\text { (2002) }\end{array}$ \\
\hline \multirow{3}{*}{$\begin{array}{l}\text { Establishing } \\
\text { an Intervention } \\
\text { Agreement }\end{array}$} & \multirow[t]{2}{*}{ Fact Gathering } & \multirow{4}{*}{$\begin{array}{l}\text { Setting the } \\
\text { Foundation }\end{array}$} & \multirow[t]{2}{*}{$\begin{array}{c}\text { Building } \\
\text { Commitment } \\
\text { and Personal } \\
\text { Transformation }\end{array}$} & \multirow{3}{*}{$\begin{array}{c}\text { Forge a } \\
\text { Partnership }\end{array}$} & \multirow{4}{*}{$\begin{array}{l}\text { Rapport \& } \\
\text { Relationship } \\
\text { Building }\end{array}$} & $\begin{array}{c}\text { Initial } \\
\text { Contact }\end{array}$ & \multirow{4}{*}{$\begin{array}{l}\text { Relationship } \\
\text { Building }\end{array}$} & \begin{tabular}{|c|} 
Client's \& Coach's \\
Commitment \\
to the path of \\
Progressive \\
Development
\end{tabular} & \multirow{4}{*}{ Contracting } & \multirow{4}{*}{ Contracting } \\
\hline & & & & & & $\begin{array}{l}\text { Preliminary } \\
\text { Meeting }\end{array}$ & & Characteristics of & & \\
\hline & \multirow{4}{*}{$\begin{array}{l}\text { Planning and } \\
\text { Consolidation }\end{array}$} & & \multirow{4}{*}{$\begin{array}{c}\text { Moving the } \\
\text { Executive Forward }\end{array}$} & & & $\begin{array}{c}\text { Joint Goal- } \\
\text { Setting }\end{array}$ & & \& Issues & & \\
\hline $\begin{array}{l}\text { Building a coaching } \\
\text { relationship }\end{array}$ & & & & \multirow{3}{*}{$\begin{array}{c}\text { Inspire } \\
\text { Commitment }\end{array}$} & & $\begin{array}{l}\text { Contract } \\
\text { Approval }\end{array}$ & & $\begin{array}{l}\text { Structure of } \\
\text { Coaching } \\
\text { Relationship }\end{array}$ & & \\
\hline $\begin{array}{l}\text { Creating and } \\
\text { Maintaining } \\
\text { Expectations of } \\
\text { Success }\end{array}$ & & $\begin{array}{l}\text { Assessment of } \\
\text { the Individual }\end{array}$ & & & Assessment & $\begin{array}{c}\text { Formal } \\
\text { Assessment }\end{array}$ & \multirow[t]{2}{*}{ Assessment } & \multirow[t]{2}{*}{$\begin{array}{l}\text { Client-coach } \\
\text { Relationship }\end{array}$} & \multirow[t]{2}{*}{ Assessment } & \multirow[t]{2}{*}{$\begin{array}{l}\text { Data } \\
\text { Collection }\end{array}$} \\
\hline \multirow[b]{2}{*}{$\begin{array}{l}\text { Experiences of } \\
\text { Mastery and } \\
\text { Cognitive Control }\end{array}$} & & \multirow{2}{*}{$\begin{array}{l}\text { Developmental } \\
\text { Planning } \\
\text { (Feedback \& } \\
\text { Development } \\
\text { Plan) } \\
\end{array}$} & & & $\begin{array}{l}\text { Providing } \\
\text { Feedback }\end{array}$ & Feedback & & & & \\
\hline & & & & $\begin{array}{l}\text { Promote } \\
\text { Persistence }\end{array}$ & $\begin{array}{l}\text { Planning for } \\
\text { Action }\end{array}$ & Coaching & Intervention & $\begin{array}{c}\text { Quality of } \\
\text { Coaching } \\
\text { Interventions }\end{array}$ & $\begin{array}{l}\text { Goal-Setting / } \\
\text { Action Planning }\end{array}$ & \\
\hline & & & Facilitating & & $\begin{array}{c}\text { Organizing } \\
\text { Change }\end{array}$ & & & Adherence & & \\
\hline $\begin{array}{l}\text { Attributing } \\
\text { Coaching }\end{array}$ & Development & Implementation & $\begin{array}{l}\text { the Personal } \\
\text { Transformation }\end{array}$ & $\begin{array}{l}\text { Shape the } \\
\text { Environment }\end{array}$ & $\begin{array}{l}\text { Reviewing } \\
\text { Progress }\end{array}$ & & Follow-up & Protocol & Implementation & Coaching \\
\hline $\begin{array}{l}\text { Successes and } \\
\text { Failures }\end{array}$ & & & & & $\begin{array}{l}\text { Thinking } \\
\text { Ahead }\end{array}$ & Termination & Evaluation & \begin{tabular}{|c|} 
Client's \& Coach's \\
Organizational \\
Setting
\end{tabular} & & \\
\hline
\end{tabular}

suboutcomes, or significant events in the coaching process, yielded a new level of awareness for the respondents, about their patterns of behaviour and their impact on their organizations. Coachees used expressions such as "revelations" or "realizations," terms which resonate with the definition of insight as presented in the study by Ménard, 2013 [1]: "a sudden and personal construction of a new meaning expressing a truth that modifies one's perception of the world."

De Hann \& al. [18] observe two areas of personal realization in their study. The first area relates to a new knowledge and understanding of a situation, of others, or of ideas for solutions. The second area pertains to the self and to one's way of behaving, and the impact of this behaviour on others and on one`s organization. These two areas of insight described by De Hann \& al. [18] are presented as types of insight in Ménard's [1] study. Admittedly, Ménard [1] considers that several types of insight do exist, resulting from a combination of experiential and rational processes generating new awareness and understanding in relation to an immediate situation or a trend across time from past situations.

More specifically, Ménard [1] explores the phenomenon of insight using Pascual-Leone and Greenberg's [19] model of insight. Their model stipulates that awareness and experiential metaawareness are two types of what is known as experience-near insight, and these are contrasted with two types of more experience-distant insight called rational meta-awareness and conceptual linking. There are four types of insight, consisting of qualitatively different processes that fall along a continuum, from experience-near to experiencedistant: these are experiential insight, experientialexistential insight, cognitive-behavioural insight, and psychodynamc insight.

Ménard [1] observed significant events across seven coach-coachee dyads over a six-month period in search of the four types of insight as presented by Pascual-Leone and Greenberg's [19] model of insight. The number of coaching sessions varied from three to seven per dyad, and their average duration was 62 to 77 minutes per session. The intervals between sessions were two to four weeks, and all clients participated on a voluntary basis. Four of the seven clients were intermediate-level managers from the same academic institution in Canada. Their employer offered coaching services as a new organizational development initiative. Two of the three other clients working for government agencies were senior-level managers, and the third was at the intermediate level. After each coaching session, each client was invited to fill out a short questionnaire on significant events. If a client responded that he or she had experienced a significant event, responses to that questionnaire were then compared to the definitions and examples of the four types of insight, as presented by PascualLeone and Greenberg [19] in their model. Following an analysis of the significant event reported and confirmation of the presence of one or more types of insight, a brief structure-recall interview was 
conducted with the executive coach. The interview yielded a better understanding of the coach's intervention before and during the emergence of insight during coaching sessions.

Out of 36 coaching sessions observed, 28 significant events were reported and of these, 38 instances involving insight were identified: 13 experiential insight, 14 existential insight, and 11 cognitive-behavioural insight. Common to all three types of insight observed were interventions by coaches that are specific to executive coaching, such as exposing effective and ineffective behaviours and encouraging new behaviours. In addition, generic interventions such as communicating information to the client; asking the client to verbalize without revealing the type of information hoped for; and inviting verbalization on facts, emotions, intentions and ideas; all were reported by coaches and observed by the researcher.

To a certain extent, the intervention strategies observed in Ménard's [1] study seem to complement De Hann \& al.'s [18] model of taxonomy of clients' metaphors describing how they experience significant events during coaching. For example, in their analysis of the metaphors used by clients, De Hann \& al. [18] find two sets of polarities: incremental vs. generative change, and internal vs. external processing. They also create four dimensions which, they infer, are the main distinctions clients make in relation to the two sets of polarities. These dimensions are: agency, tools, realization, and way-of-being. Furthermore, De Hann $\&$ al. [18] map out these polarities and dimensions as a sequence of seven steps:

1) Agency (actions)

2) Incremental change (journey)

3) Tools

4) Internal process

5) Realization (insight)

6) Generative change (transformation)

7) Way-of-being

The sequence proposed by the researchers [18] maps out their interpretation of metaphors heard from coachees, as well as the process of learning and change in executive coaching. The process they propose reflects a dynamic, deepening exploration of the client's experience, and this aligns with the executive coaches' intervention strategies that are common to the three types of insight [1]. The intervention strategies presented by Ménard [1] reflect a dynamic, coach-to-coach dialogue process on specific circumstances brought forward by clients.

The intervention strategies allow the client to reflect upon and discuss each circumstance, such that insight emerges and allows a new awareness and understanding to take place. Although Ménard's [1] intervention strategies common to three types of insight do not correspond to the specific steps listed in the model of taxonomy of clients' metaphors [18], the process of deepening reflection and understanding seems to be shared, not only by each client's metaphor describing his or her experience of significant events during coaching in De Hann \& al.'s [18] study, but also intervention strategies related to the types of insight described in Ménard's [1] study.

\section{Conclusion}

In conclusion, the nature of the interactions among coachees and their environment, the tools they use within these interactions, the activity itself, and the social context within which the activity takes place, all shape their learning. In their study on clients' significant events during executive coaching, De Hann \& al., [18] were able to find that breakdowns in the coaching relationship were observed in the absence of shared reflections between coach and coachee, at points of tension during coaching sessions. When both clients and coachees were able to reflect in the moment, learning and insight often resulted. De Hann \& al.'s [18] study describes the importance of the coach and coachee relationship as well as the importance of reflecting on one's own inner world and experience. Ménard's [1] study sheds light on coaching strategies observed in the presence of three types of insight: experiential insight, existential insight, and cognitive-behavioural insight. These strategies relate to dialogue in support of reflection in the moment, allowing the layers of the coachee's experience to unfold, leading to deep learning.

Executive coaching is a powerful learning process for developing leadership competencies [5]. It is a rigorous, personalized, tailored and multiphased approach to each coachee's learning and development needs. Moreover, learning in executive coaching is experiential in nature, which leads to transformational, self-directed learning. These types of learning are perfectly suited to the development of the relational capabilities that characterize effective leadership.

\section{References}

[1] S. Ménard, "L'étude des relations entre les stratégies d'intervention des coches et les types d'insight dans le coaching de dirigeants" (Unpublished doctoral dissertation). Université du Québec en Outaouais, Gatineau, CA, 2013,http://www.archipel.uqam.ca/ 6103/1/D2638.pdf.

[2] A.M. Grant, \& M. Cavanagh, "Toward a profession of coaching: sixty-five years of progress and challenges for the future", International Journal of Evidence based Coaching and Mentoring, Oxford Brookes University Business School, Oxford, UK, 2(1), 2004, pp. 7-21. 
[3] M.E. Dingman, "The effects of executive coaching on job-related attitudes" (Unpublished doctoral dissertation), Regent University, School of Leadership Studies, Virginia Beach,VA, 2004.

[4] F. Kiel, E. Rimmer, K. Williams, \& M. Doyle, Coaching at the top. In R.R. Kilburg \& R.C. Diedrich (Dir.), The wisdom of coaching, American Psychological Association, Washington, DC, 2006.

[5] R.R. Kilburg, "Toward A Conceptual Understanding and Definition of Executive Coaching", Consulting Psychology Journal: Practice and Research, American Psychological Association, Washington, VA, 48, 1996, pp.134-144.

[6] S. Wales, S., "Why coaching?", Journal of Change Management, 3(3), Routledge, UK, 2003, pp. 275-282.

[7] K. Weller, \& D. Weller, "In Focus/Executive coaching: Coaching and performance: Substantiating the link", Leadership in Action, Center for Creative Leadership, Greensboro, NC, 24, 2004, pp. 20-21.

[8] D. Bouteiller (Ed.), "Former pour performer. Les enjeux du développement des compétences en entreprise", Collection Racines du savoir, Revue Gestion, École des hautes études commerciales, Montréal, QC, 2000.

[9] M.W. Jr. McCall, High flyers: Developing the next generation of leaders, Harvard Business School Press, Cambridge, MA, 2008.

[10] G. Le Boterf, Construire les compétences individuelles et collectives. Agir et réussir avec compétence, les réponses à 90 questions, 3e édition, Paris, France, Cedex: Éditions d'Organisation.

[11] B.-K.B. Joo, "Executive Coaching: A Conceptual framework from an integrative review of practice and research", Human Resource Development Review, Thousand Oaks, CA, 4(4), pp. 462-488, 2005.

[12] S.B. Merriam, "Andragogy and Self-Directed Learning: Pillars of Adult Learning Theory. In S.B. Merriam (Ed.), The New Update on Adult Learning Theory. New directions for adult and continuing education, Jossey-Bass, San Francisco, CA, 2001(89), pp 3-14, 2001

[13] D.D. Pratt, "Andragogy After Twenty-Five Years", in S.B. Merriam (Ed.), Update on AdultLearning Theory, New Directions for Adult and Continuing Education, Jossey-Bass, San Francisco, CA, (57), pp 15-23, 1993.

[14] M. Knowles, The Adult Learner: A Neglected Species (3rd Ed.), Gulf Publishing, Houston, TX, 1984.

[15] A. Tough, The Adult's Learning Projects: A Fresh Approach to Theory and Practice in Adult Learning, Institute for Studies in Education, Toronto, Ontario, 1971.

[16] C.A. Hansman, "Context-Based Adult Learning", In S. B. Merriam (Ed.), In S.B. Merriam (Ed.), The New Update on Adult Learning Theory. New directions for adult and continuing education, Jossey-Bass, San Francisco, CA, (89), pp 3-14, 2001.

[17] J. Mezirow, Transformative learning: Theory to practice. In P. Cranton, (Ed.), Transformative learning in action: Insights from practice, Jossey-Bass, San Francisco, CA, 1997.

[18] E. De Haan, C. Bertie, A. Day and C. Sills, Clients' critical moments of coaching: toward a "client model" of executive coaching, Academy of Management Learning \& Education, 9(4), pp. 607-621, 2010.

[19] Pascual-Leone, A. et Greenberg, L.S. Insight and awareness in experiential therapy. In L.G. Castonguay and C.E. Hill (Eds.), Insight in psychotherapy pp. 31-56. Washington, DC, 2007. 